\title{
IMPACT OF THE VAT REVERSE-CHARGE MECHANISM ON THE CASH FLOWS OF CONSTRUCTION COMPANIES IN THE SLOVAK REPUBLIC Angelika Kútna ${ }^{1}$, Norbert Gyurián ${ }^{2}$, Zoltán Šeben $^{3}$
}

\begin{abstract}
In 2015, the Slovak Parliament adopted the Law on Amendments to the Law on Value-Added Tax. This law came into force on January 1, 2016. One of the most significant changes was the introduction of a reverse-charge for the provision of construction works. A government statement of its positive influence on the business environment is inconsistent with the two-year experience in the building sector. The main goal of this paper is to establish the reason for the practical effects of the value-added tax reverse-charge mechanism on the construction companies. The hypothesis is that the negative effect on the cash flows of the construction companies increases 'opportunity costs' connected to excessive deductions. The paper focuses on evaluating and quantifying such an effect. It presents a comparison of the conditions before and after the adoption of the Act. No. 222/2004 Coll., as amended in 2016 and includes factors that influence costs and cash flows of construction companies. It but does not consider factors related to turnover and the economic situation. The reverse-charge mechanism affects the total of tax owing, the total deductible tax, the total excessive deduction, and the construction companies' cash flows. In this study, the data from the information system of the Slovak Republic, under the condition of anonymity, are analyzed for the period 2014-2017. The effect of the value-added tax is quantified by way of financial interest expenses. These expenses depend on time limits for the excessive deduction, total of tax owing, and on the excessive deduction amount. Indicators of 'Financial Burden 1' and 'Financial Burden 2' are calculated. The results show that the Law on Amendments of Value Added Tax has significantly affected the constructions companies since January 2016. The reverse-charge system has not changed the delay in excessive deduction payments to the taxpayer's bank account. It has changed the amount of excessive deduction expressed through money and the total tax owing. Based on the study results, this change markedly affects the financial burden of construction companies and provides an 'opportunity cost' Value Added Tax payers" construction company.
\end{abstract}

JEL Classification Numbers: H25; DOI: http://dx.doi.org/10.12955/cbup.v6.1318

Keywords: value-added tax, reverse-charge, excessive deduction, construction company, interest expense

\section{Introduction}

All European countries rely on value-added tax (VAT) as the main source of government revenue (Barbone et al., 2015). The capability to generate significant amounts for the national budget is a positive aspect of the VAT, with about one-fifth of all tax revenues being collected as part of this tax globally (Borseli, 2011). This indirect tax has an important effect on state revenues (Bojňanský et al., 2013). Its popularity has gradually increased, due mainly to it being a convenient tool for the taxation of international trade (Nerudová \& David, 2008; Terra \& Kajus, 2007). The problem connected with this tax is the 'VAT gap'. Tax evasion and tax avoidance are the main reasons for the VAT gap, which is the gap between actual and 'potential' revenues that can be measured (Keen, 2013). Tax avoidance is the legal use of tax laws to reduce one's tax burden (Miller \& Pangbourne, 2010; Scott, Hanlon, \& Maydew, 2010). It is the use of the tax regime to one's advantage to reduce the amount of tax that is payable by means within the law. Pursuant to legal regulations, it is mandatory for entrepreneurs to keep current accounting records and subsequently, in the disclosure of financial statements, to provide a true and fair account of facts that are subject to accounting requirements (Ferenczi Vaňová et al. 2015). Slovak Republic belongs to the group of European Union (EU) countries with high VAT gaps, being in the fifth quintile of the EU-26 states with its average gap for 2000-2011 amounting to 29\% (Barbone, et al., 2015). The important anti-fraud measure currently specified in this proposal is the reverse-charge mechanism. Because of the principle of its neutrality, the payer can simultaneously claim input and output VAT, as was noted by Pfeiffer and Semerád (2013). According to Auerbach (2008) and Banks (2010), the value-added tax is less distortionary than other taxes for several reasons.

The value-added tax affects individual businesses differently. It increases both start-up and ongoing operating costs but the effect is stronger in small- and medium-sized enterprises (Azmi, 2016). The reverse-charge mechanism is a measure that is intended to simplify the procedure for assessing value-

\footnotetext{
${ }^{1}$ J. Selye University, Faculty of economics, Management department, Komárno, Slovak Republic, Financial

Directorate of the Slovak Republic, angelika.kutna@gmail.com

2 J. Selye University, Faculty of economics, Management department, Komárno, Slovak Republic, ngyurian@gmail.com

${ }^{3}$ J. Selye University, Faculty of economics, Management department, Komárno, Slovak Republic, sebenz@ujs.sk
} 
added tax and assist in preventing tax evasions and the avoidance of tax liabilities in certain fields and for certain types of fulfillment (Berger et al., 2010). The EU continually allows an exception from the general mechanism for an individual Member State. However, each Member State has, according to Rambousek (2012), a problem with other commodities and tries to resolve the problems in this field by 'reverse charge'. For example, Portugal is facing fraud claims over frozen fish, Hungary with purchase of scrap, and the Czech Republic has problems in the field of fuel. The Slovak Republic has a similar problem with construction works.

The main aim of this paper is to establish the influence of the value-added tax reverse-charge mechanism as a reason for an 'opportunity cost' in the construction companies. The basic principle of the reverse-charge mechanism is shifting the tax burden from the supplier to the recipient of the construction works supply (final customer or subscriber). This mechanism has economic consequences for taxpayers. The European's common system of VAT in the European Union member states is based on the Council Directive 2006/112/EC (2006). This directive unifies the rules for applying the tax within the Member States of the European Union. Implementing the European's common system of VAT in the Slovak tax law was one of the conditions of the European Commission during the accession negotiations. The date of the Slovak Republic's accession to the European Union was also the first day of the validity of the new Slovak VAT Law, Act No. 222/2004 Coll. on Value Added Tax, as amended. According to Article 199 of the VAT Directive, the Member States can optionally apply a reverse-charge mechanism to a special type of transaction belonging to construction works. The approval of the Quick Reaction Mechanism (Council Directive 2013/42/EU) can be regarded as the next milestone in this area. The scheme makes it possible to introduce a local reversecharge mechanism for problematic goods and services in terms of the tax. The mechanism is based on the same principles that apply to intra-community transactions (trading between at least two EU Member States). The provider of the taxable supply issues an invoice without VAT. There are an exemption and zero tax rates. The recipient of the taxable supply is required to pay tax on the same supply, i.e., paying 'output VAT'.

This paper focusses on the effect of the value-added tax reverse-charge mechanism on construction companies in the Slovak Republic. The research is based on the comparison of the value-added tax effect on the cash flows of construction companies in the Slovak Republic before and after the adoption of the Act. 222/2004 Coll., as amended (2016).

\section{Data and Methodology}

The taxpayer group examined in this study comprised companies selected from the databases of the Financial Administration Slovak Republic. According to the main international statistical classification, these companies belonged to Sector F, divisions F41 (construction of buildings), F42 (civil engineering), or F43 (specialized construction activities). These were 158 companies that were recorded in the Slovak Companies Register and registered in the Slovak Financial Directorate as VAT monthly payers.

Data were sought from the sources:

- Intranet portal of the Slovak Financial Directorate information system

- VAT tax returns submitted by the taxpayers; and

- VAT control statements submitted by taxpayers.

Data for 2014-2017 were analyzed. This period was chosen to cover the conditions before and after the adoption of the Act 222/2004 Coll. as amended in 2016. Standard methods of scientific work were used in selecting, analyzing and the comparing selected provisions of this act including related law. Descriptive statistical methods were used in analyzing and comparing indicators for the reporting period (arithmetic average, base index).

Financial burden results from the time shifting period between the day of VAT tax return submission to the Financial Directorate by electronic means (this is the day of taxpayer`s entitlement to excessive deduction) and the validity day (day, when the taxpayer receives payment to his bank account from the Financial Directorate).

The indicators of 'value of money 1' and 'value of money 2' were calculated using the following equations. 
Indicator 'Financial Burden 1'= principal $\times$ interest rate of the European Central Bank $(\mathrm{ECB}) \times$ average loan term $\div 365$

Indicator 'Financial Burden 2' $=$ principal $\times$ average commercial interest rate $\mathrm{x}$ average loan term $\div$ 365.

Where

Principal $=$ the average amount of excessive deduction of constructions companies

Average loan term $=$ the period during which the constructions companies lend money to the state budget (with the state the borrower in this case)

$365=$ the number of days in a year

Interest rates of the ECB and the average commercial interest rate are presented in Table 2.

The following includes the assumptions of this research:

- Data were obtained from VAT returns. The tax period applicable to a taxpayer was a calendar month. The tax return was submitted within 25 days of the end of each tax period by each taxpayer.

- Ninety-five percent of taxpayers submitted their tax return on the last day or on the day before the second last day of their obligation. That is, taxpayers submitted the tax return on the 25 th, 24th, or 23rd day after the end of the tax period.

- The period from the day when a taxpayer was entitled to an excessive deduction to the day of deducting this amount from the tax owing in the next tax period was 61-64 days. The period of 64 days (period 1) is considered in the analysis.

- The day when a taxpayer was entitled to an excessive deduction to the day of its returning to the tax payer`s bank account is a period of 90-93 days. The period of 93 days (period 2) is considered in the analysis.

- The day when a taxpayer is entitled to an excessive deduction after the terminated tax audit is 180 days on average (period 3 ) is considered in the analysis.

- The day when a taxpayer is entitled to an excessive deduction after the terminated tax audit and international exchange of information between the Member States is 360 days on average (period 4) and is considered in the analysis.

- The length of period and the excessive deduction are the most significant factors that influence the extent of the effect of the VAT on taxpayers' cash flows.

The four most frequent and thus, most relevant periods for returning the excessive deduction are presented in Table 1.

Table 1: The length of periods for returning the excessive deduction (days)

\begin{tabular}{|l|l|l|l|l|l|r|}
\hline $\begin{array}{l}\text { Construction of period according } \\
\text { to rules 1-7 }\end{array}$ & $\mathbf{1 .}$ & $\mathbf{2 .}$ & $\mathbf{3 .}$ & $\mathbf{4 .}$ & $\mathbf{5 .}$ & $\begin{array}{l}\text { Final } \\
\text { period } \\
\text { (days) }\end{array}$ \\
\hline $\begin{array}{l}\text { Deducting excessive deduction } \\
\text { (days) }\end{array}$ & 15 & 24 & 25 & & & 64 \\
\hline $\begin{array}{l}\text { Returning excessive } \\
\text { deduction(days) }\end{array}$ & 15 & 24 & 24 & 30 & & 93 \\
\hline Tax audit 180 days (days) & 15 & 24 & 24 & 30 & 180 & 273 \\
\hline Tax audit 360 days (days) & 15 & 24 & 24 & 30 & 360 & 453 \\
\hline
\end{tabular}

Source: Authors

Table 2: The ECB and commercial bank average interest rates in the Slovak Republic 2014-2017

\begin{tabular}{|l|c|c|c|c|}
\hline & $\mathbf{2 0 1 4}$ & $\mathbf{2 0 1 5}$ & $\mathbf{2 0 1 6}$ & $\mathbf{2 0 1 7}$ \\
\hline IR ECB & 0.40 & 0.35 & 0.25 & 0.25 \\
\hline IR CB & 3.31 & 3.08 & 2.69 & 2.43 \\
\hline
\end{tabular}

Source: www-ext.nbs.sk/en/statistics/exchange-rates/exchange-rates-nbs 


\section{Results and Discussion}

The construction services (including the supply of materials) were subject to VAT at the standard rate until the end of 2015. During 2014-2015, the construction companies were under pressure in terms of meeting the additional requirement of paying for services at $20 \%$ VAT on the purchase of construction services accrued each month. As Figure 1 shows, in 2016, the situation changed. The average tax owing in 2016 was 50 times less than that of 2015. In contrast, the average amount of excessive deduction had increased 21 times, approximately. Figure 1 shows the average monthly excessive deduction amounts in which the zero value was most frequent in 2015 (eight times). This situation arose because, before 2016, the tax liability of construction companies concerned the supply of a construction service. In 2016, the average monthly excessive deduction was EUR 2263155 . The average deviation in this period was less than 10\%, at about EUR 221 732. In 2017, the situation did not change in a significant way. The average monthly excessive deduction was EUR 2024524 and average deviation was about EUR 419755 (January and December seasonal deviation). The reversecharge mechanism and the subsequent excessive deduction have a significant effect on the cash flows of construction companies, as is shown later in this paper. The average total of tax owing in 2014 was EUR 3265328 and this increased by nearly 100\% to EUR 6046766 in 2015. As the result of the new VAT law amendment, in 2016 it was only EUR 115309 on average. After the modification of the control statement (part A2 creation), the average total of tax owing in 2017 was EUR 1192117.

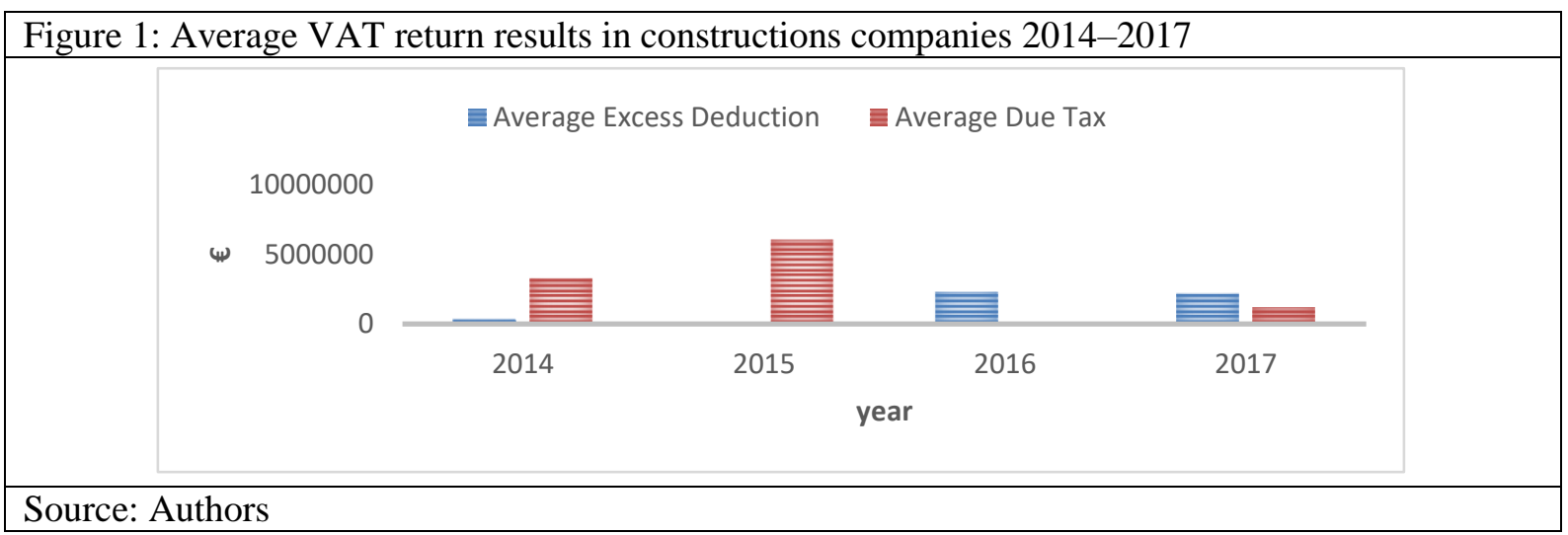

Figure 2 shows the development of excessive deduction in construction companies during 2014-2017 and the marked impact of the reverse-charge mechanism with higher amounts shown for 2016 and 2017. The construction companies that provide most of the construction works began to apply the reverse-charge mechanism not only for the supply of work on output but also on the connected supply of construction materials. The output tax in these entities started at about zero or with low numbers and generally resulted in an excessive deduction from the purchase of building materials and the purchasing or leasing of machinery. The construction companies have to contend with the period for return of the excessive deduction from the state budget. Refund of the excessive deduction by the tax office will mean the companies have been reimbursed the money that they had paid to suppliers on purchasing materials. However, there is a time lag in the payment. In the cases of a tax audit, this period will be longer (Table 1) and is the main cause of the financial tax burden.

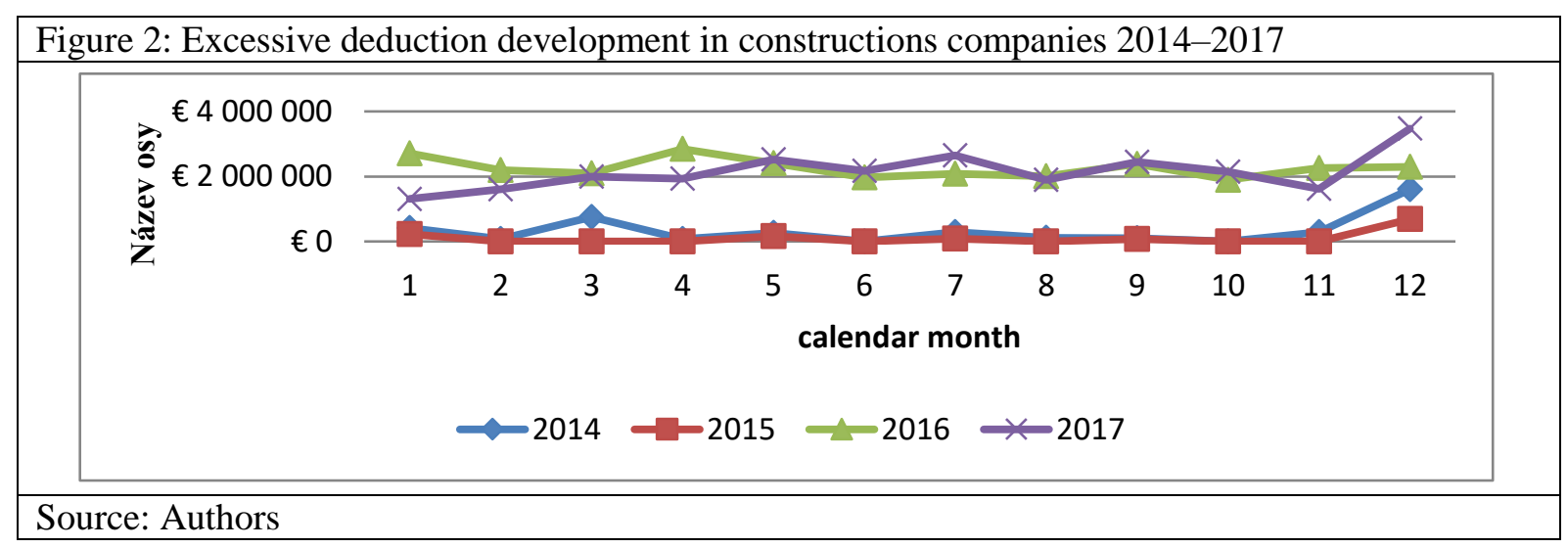


In cases where the construction works are done directly by the construction company and for a nonpayer, the VAT will be paid on the output, using a standard mechanism, and the reverse-charge mechanism will have no effect on the entity. The development of tax owing over the period 20142017 is shown in Figure 3. The tax due in the month of December (12) is lower than other months, though the tax duties for other months have similar development. The much lower values that are shown from 2016 indicate the effect of the reverse-charge mechanism. For illustration, the highest monthly value in 2015 was about EUR 10252027 in September of that year. In 2016, the highest monthly value was only EUR 273001 . After the modification of the control statement (part A2 creation), the maximum total of tax owing in 2017 was EUR 1192117.

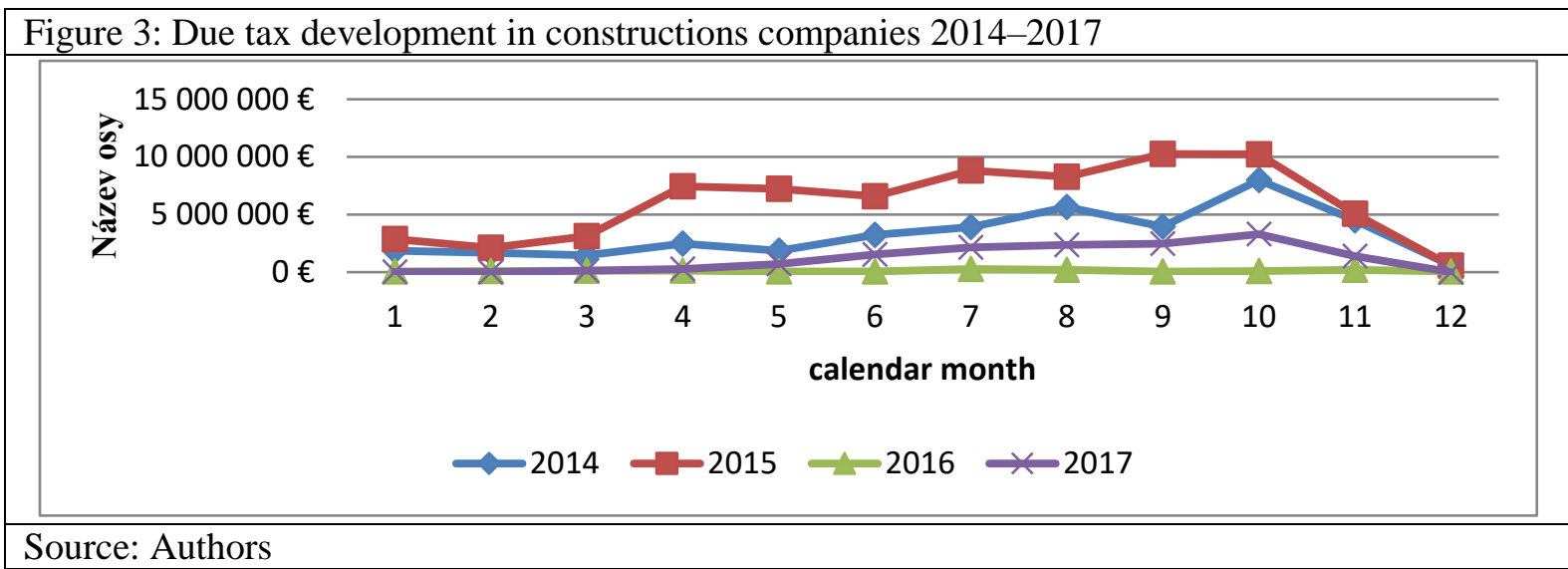

For the construction companies, the reverse-charge mechanism has had an important effect on cash flows, not only for the recipient but also for the provider of the building works. With the reversecharge mechanism, the recipient must consider both the output and the input tax deduction on the same transaction. If a company has the full or partial claim to a tax deduction in the frame of their tax returns, the reverse-charge mechanism can have a positive or negative impact on the cash flow of such taxpayers. For illustration, Table 3 presents the average financial burden caused by the different lengths of the period for returning the excessive deduction to a construction company in 2017 (ECB rates).

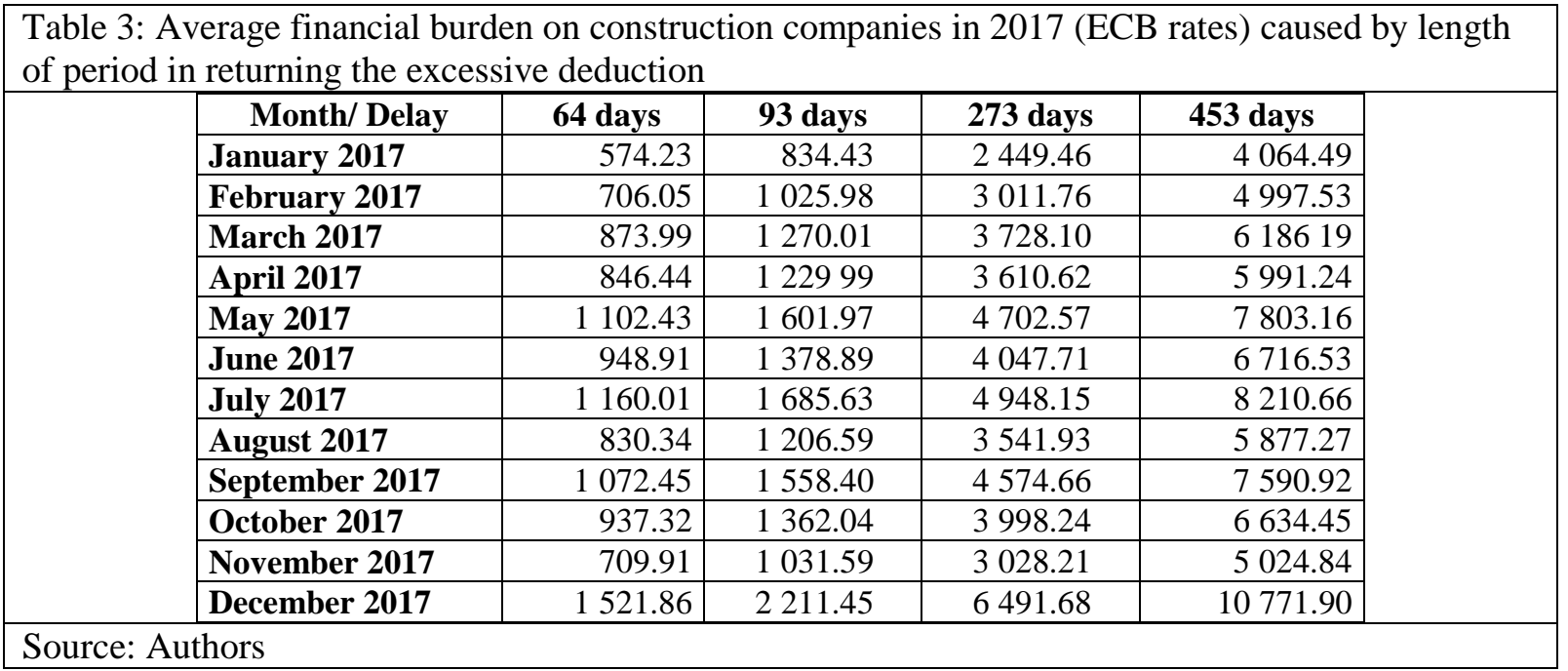

The financial burden increased with the length of the period for returning the excessive deduction. In the cases of tax audit (period 3, representing a lag of 273 days, and period 4 representing a lag of 453 days), it was higher. The reverse-charge mechanism had the most significant influence, which was reflected in the excessive deduction amount, a multiple of the burden amount. The ECB interest rates, being the multiplier, did not change significantly in the period 2014-2017. The most standard and frequent was the period of 93 days (lags of 64, 283, and 453 were less than 5\% of all cases). The average for Financial Burden 1 for the lag of 93 days amounted to EUR 338.08 in 2014 and EUR 77.62 in 2015. The ECB rates decreased by 0.5 of a point. After 2016, the ECB rates again decreased 
by about 0.1 of a point but, because of the reverse-charge mechanism, the Financial Burden 1 increased on average to EUR 1441.60 in 2016 and to EUR 1366.42 in 2017.

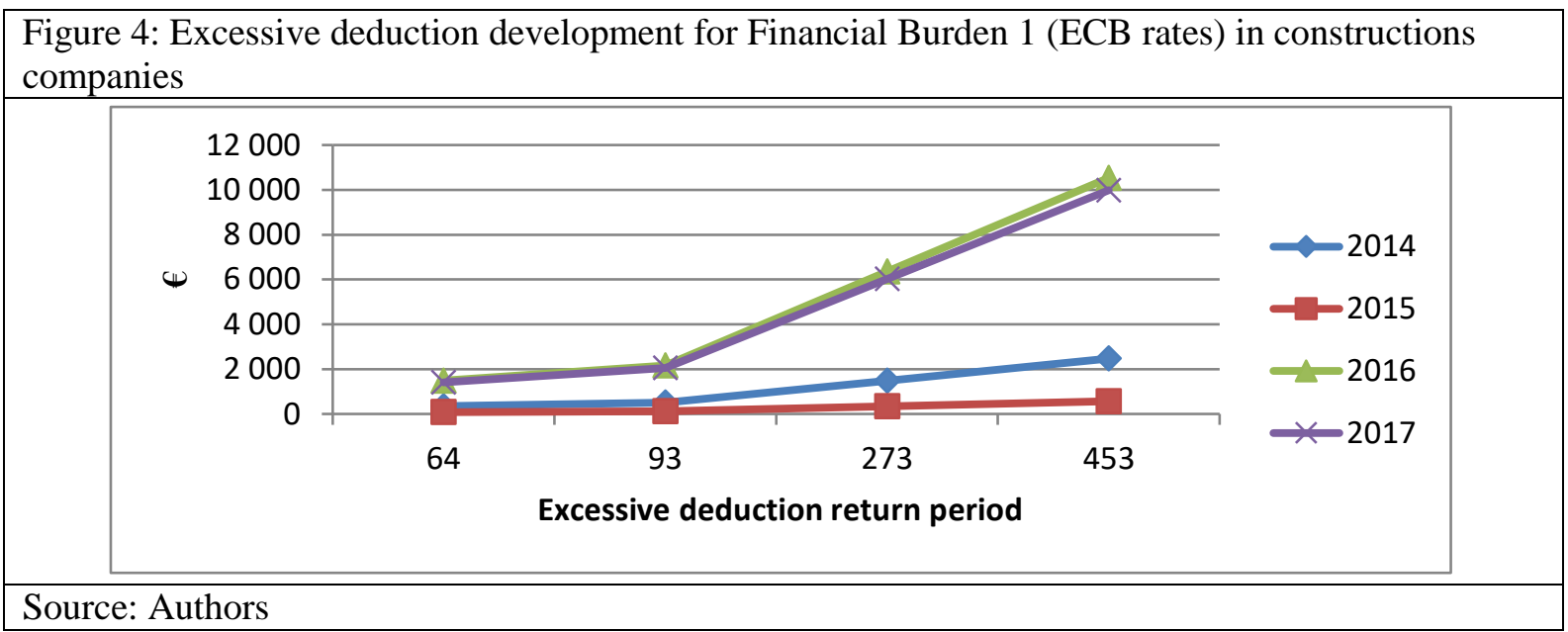

Figure 5 presents the development of excessive deduction in terms of Financial Burden 2 (commercial rates) in construction companies. These values are closer to the economic experience because of the external financial sources. Most companies in the construction sector need to refinance their economic activities when borrowing money and pay interest to commercial financial institutions, rather than to the ECB. The reason for the difference between Financial Burden 2 (commercial rates) and the Financial Burden 1 (ECB rates) corresponds to the difference between the ECB and commercial rates. For Financial Burden 2, the average was EUR 2797.53 in 2014 and EUR 796.92 in 2015 for the 93day period. The new reverse-charge mechanism multiplied the financial burden several times and amounted to EUR 15511.60 in 2016 and EUR 13281.56 in 2017. These financial costs influenced the economic outcome of the companies.

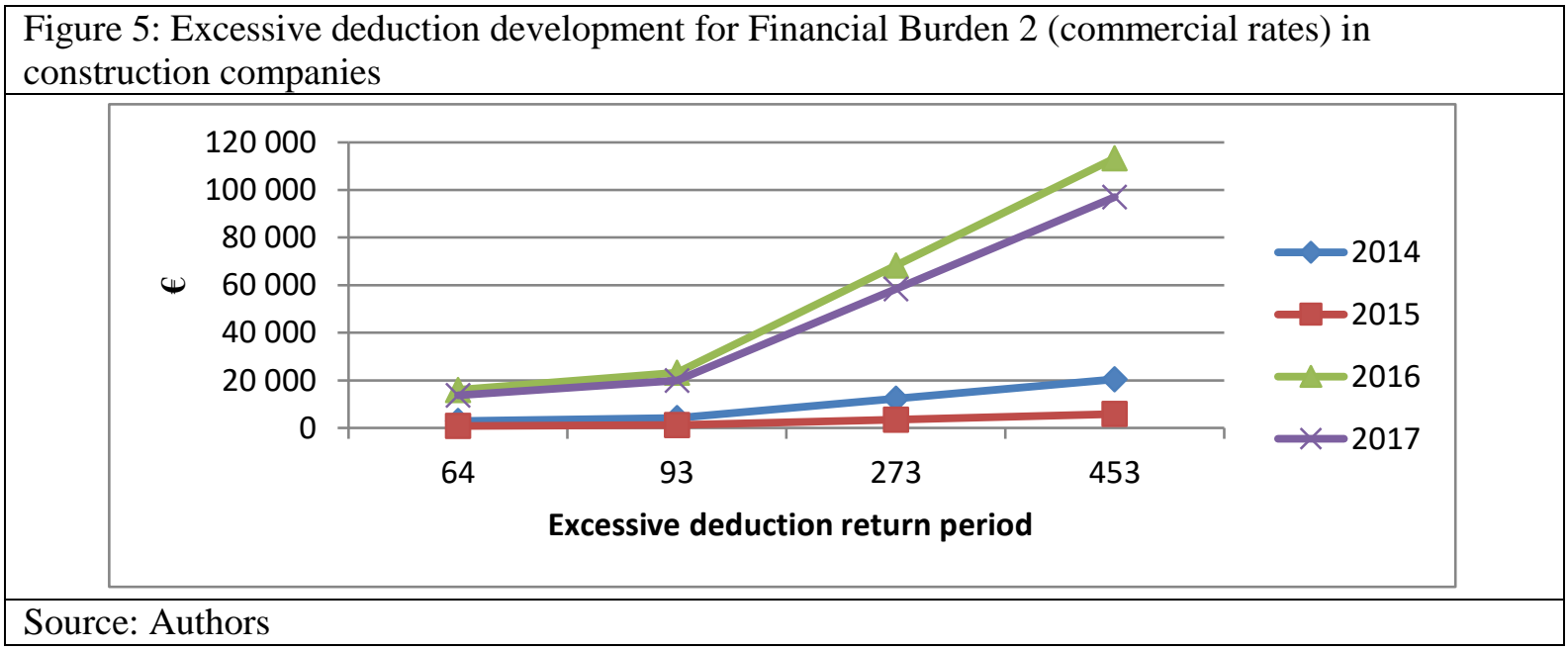

\section{Conclusion}

The implementation of the reverse-charge mechanism aimed to minimize the existing tax fraud and eliminate the situation of a supplier failing to pay 'output VAT' while the customer declared a right to deduct this tax. The analysis presented in this paper shows that the reverse-charge on provisions from construction works had important economic consequences for the construction companies. The paper aimed to evaluate and quantify this impact and the results presented indicate that the reverse-charged mechanism has caused financial costs that influenced not only the cash flows but also the economic outcome of the companies. The results of this research can be used for future legislative processes concerning the VAT law to improve the business environment in the building sector. Future research could consider the possible influence of certain other factors that cause opportunity costs in the building sector or in other companies (or other economic sectors). 


\section{References}

Azmi, A., \& Noor, S. S. (2016). SMEs' tax compliance costs and IT adoption: the case of a value-added tax. International Journal of Accounting Information Systems, 23. (pp. 1-4)

Auerbach, A. J. (2008). Tax reform in the twenty-first century. In J. W. Diamond \& G. R. Zodrow (Eds.). Fundamental tax reform: issues, choices and implications. The MIT Press. Cambridge, pp. 27-74

Banks, J. W., \& Diamond, P. A. (2010). The base for direct taxation. In Institute for Fiscal Studies (Ed.). Dimensions of tax design. Oxford University Press. New York (548-648),

Barbone, L., Bonch-Osmolovskiy, M. and Poniatowski, G., Study to Quantify and Analyze the VAT Gap in the EU Member States (September 2015). CASE Network Reports No. 124. Available at

SSRN: https://ssrn.com/abstract=2693524 or http://dx.doi.org/10.2139/ssrn.2693524

Barb one, Lea t al. (2013): Study to quantify and analyses the VAT gap in the EU-27 member states, CASE Network Reports, No. 116, ISBN 978-83-7178-598-6

Berger, W., Kindle, C., Wakening, M., 2010: Service ES o dana z priding honesty - praktický komentár. 1. vyd. Praha: 1. VOX, 734 s. ISBN 978- 80-86324-83-8.

Borseli, F. (2011). Organised VAT fraud: features, magnitude, policy perspectives. Banca D'Italia: Questioni di Economia e Finanza. Commission Commission Recommendation of 6 May 2003 concerning the definition of micro, small and mediumsized enterprises (notified under document number C(2003) 1422) (2003/361/EC).

Bojňanský, J., Krajčírová, R., \& Ferenczi Vaňová, A. (2013). Dane podnikatel’ských subjektov. (Taxes of entrepreneurs.) Nitra: SPU, $251 \mathrm{~s}$.

Ferenczi Vaňová, A., Krajčírová, R., Váryová, I., Košovská, I. Depreciation influence of fixed assets on accounting result and corporate income tax base pursuant accounting and tax legislation in the Slovak Republic. In Finance and performance of firms in science, education and practice. Zlín : Tomas Bata University in Zlín, 2015. s. 287--296. ISBN 978-80-7454-482-8. URL: http://www.slpk.sk/eldo/2015/zborniky/9788055213491.pdf.

Keen, M. (2013): "The Anatomy of the VAT”, IMF Working Paper, WP/13/111, May.

Miller, J. and Pangbourne, T., 2010. Tax avoidance schemes: the liability of professional advisers, Professional Adviser (1743-3339).

Nerudová, D. \& David, P. (2008). Empirical Study of Specific Value Added Tax Problems in Selected European Union Member States. European Financial and Accounting Journal. 3, 70-91. Keen, M. (2013): "The Anatomy of the VAT", National Tax Journal 66 (2): 423-446.

Pfeiffer, S. \& Semerád, P. (2013). Missing Trader Fraud in European VAT. Mendelu Working Papers in Business and Economics. Available from: http://econpapers.repec.org/paper/menwpaper/41_5f2013.htm

Scott D. Dyreng, Michelle Hanlon, and Edward L. Maydew (2010) The Effects of Executives on Corporate Tax Avoidance. The Accounting Review: July 2010, Vol. 85, No. 4, pp. 1163-1189.

Terra, B. \& Kajus, J. (2007). A guide to the European VAT Directives: Introduction to European VAT 2007. IBFD.

SMĚRNICE RADY 2006/112/ES, ze dne 28. listopadu 2006, o společném systému daně z přidané hodnoty, [online] [cit. 2012-12-14]. Dostupné z http:// eur-lex .europa .eu/LexUriServ/LexUriServ. do?uri=OJ:L:2006:347:0001:0118:cs 